Brazilian Journal

of Chemical

ISSN 0104-6632

Engineering

\title{
EFFECT OF SULFATE LOADING RATE AND ORGANIC LOADING RATE ON ANAEROBIC BAFFLED REACTORS USED FOR TREATMENT OF SANITARY LANDFILL LEACHATES
}

\author{
O. Burbano-Figueroa ${ }^{1 *}$, M. Jaramillo ${ }^{1}$, M. Moreno-Moran ${ }^{2}$ and P. Fernández-Izquierdo ${ }^{1}$ \\ ${ }^{1}$ Departament of Biology, Faculty of Exact and Natural Sciences, Universidad de Nariño, \\ Ciudad Universitaria Torobajo - Calle 18 Cr 50, San Juan de Pasto, Nariño, Colombia. \\ Phone: + 011-572-7313106, Fax: + 011-572-223315 \\ *Present address: CI. Turipaná, Corporación Colombiana de Investigación Agropecuaria, \\ CORPOICA, Km 14 vía Montería-Cereté, Córdoba, Colombia. \\ E-mail: burbano-figueroa.1@buckeyemail.osu.edu \\ ${ }^{2}$ Specialized Labs, Universidad de Nariño, Ciudad Universitaria Torobajo, Pasto, Nariño, Colombia.
}

(Submitted: January 18, 2014 ; Revised: June 14, 2014 ; Accepted: June 16, 2014)

\begin{abstract}
This study investigated the effect of organic loading rate (OLR) and sulfate loading rate (SLR) on landfill leachate treatment by a lab-scale anaerobic baffled reactor (ABR). Landfill leachate contained a concentration of organic matter between 3966 and $5090 \mathrm{mg}$ COD.L $\mathrm{L}^{-1}$ and no detectable amounts of sulfate. Reactors were started-up by feeding them with iron-sulfate at a SLR of $0.05 \mathrm{~g} \mathrm{SO}_{4}{ }^{2-} \cdot \mathrm{L}^{-1} \cdot$ day $^{-1}$ (4 weeks). Factorial design and response surface techniques were used to evaluate and optimize the effects of these operating variables

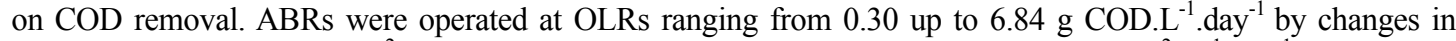
influent volumetric flow. $\mathrm{SO}_{4}{ }^{2-}$ was added to the influent at a SRL from 0.06 to $0.13 \mathrm{~g} \mathrm{SO}_{4}{ }^{2-} \cdot \mathrm{L}^{-1}$.day ${ }^{-1}$. The highest value of COD removal (66\%) was reached at an OLR of $3.58 \mathrm{~g} \mathrm{COD.L^{-1 } \cdot \mathrm { day } ^ { - 1 } \text { and SLR of } 0 . 0 9 \mathrm { g } \mathrm { SO } _ { 4 } ^ { - 2 } \cdot \mathrm { L } ^ { - 1 } \text { .day }}{ }^{-1}$ with a $\mathrm{COD} / \mathrm{SO}_{4}{ }^{-2}$ ratio of 40 . Under these conditions sulfate is mainly used for molecular hydrogen consumption while organic matter is preferentially degraded via methanogesis.
\end{abstract}

Keywords: Antanas sanitary landfill; Anaerobic baffled reactor; Response surface methodology; COD/sulfate ratio.

\section{INTRODUCTION}

In Colombia, sanitary landfills are the most common method for the disposal of municipal solid wastes (SSPD, 2008). More than half of all municipalities dispose their wastes in local or regional sanitary landfills and less than $10 \%$ use a solid waste integrated facility (SSPD, 2008; Noguera and Olivero, 2010). Leachate production is considered the most complex environmental issue related with sanitary landfills (Bashir et al., 2010; Kulikowska and Klimiuk, 2008; Ghafari et al., 2009). Landfill leachate contains significant amounts of organic matter and inorganic salts, especially heavy metals, which can contaminate groundwater and surface water far away from the original location (Tchobanoglous, 2002).

Leachates are treated by different technologies specific to each country, type of solid waste and cost. The most common technologies used for leachate treatment can be classified into three groups: i.) recycling and combined treatment with municipal domestic sewage, ii.) biological treatment under aerobic or anaerobic conditions or a mix of these, and iii) chemical/physical methods (Renou et al., 2008). In

*To whom correspondence should be addressed 
addition to its simplicity and reliability, biological treatment is the best cost-effective strategy for the treatment of landfill leachate (Wiszniowski et al., 2006; Renou et al., 2008). Anaerobic biological processes have economic advantages resulting from lower energy consumption and solid production when compared with aerobic process. The major disadvantage of the anaerobic process is its low rate of reaction. Consequently it requires stable operating conditions and warm temperatures $\left(35^{\circ} \mathrm{C}\right)$ (Berrueta and Castrillón, 1992). Anaerobic reactors treating landfill leachates at temperatures lower than $35^{\circ} \mathrm{C}$ require the use of high performance treatment technologies (Kettunen et al., 1996; García et al., 1996).

Antanas Sanitary Landfill (ASL) serves as a regional landfill for the central region of Nariño Province in the Southwest of Colombia. ASL is located at an elevation of 2750 masl (meters above sea level) with an average temperature of $12{ }^{\circ} \mathrm{C}$. Anaerobic reactors used for ASL leachate treatment exhibit poor performance even when they are operated at low OLRs (less than 1 g.. - $^{-1}$.day ${ }^{-1}$ ) (Burbano-Figueroa, 2002). Anaerobic reactors require temperatures higher than $18{ }^{\circ} \mathrm{C}$ for optimal performance. At low reaction rates, molecular hydrogen accumulates, resulting in inhibition of methanogenesis and VFA degradation (García et al., 1996; Kettunen et al., 1996; Lettinga et al., 1999). High anaerobic reaction rates can be achieved if hydrogen is depleted by oxidation with a suitable electron acceptor. Sulfate can accomplish this role in a cost-effective way with a low environmental impact (JWH et al., 1994, Kalyuzhnyi et al., 1998; Dar et al., 2009; Zhao et al., 2010).

Sulfate-reducing bacteria (SRB) can remove molecular hydrogen, allowing optimal performance of methanogenic microorganisms (JWH et al., 1994; Kalyuzhnyi et al., 1998; Dar et al., 2009; Zhao et al., 2010). Under anaerobic conditions, SRB, alone or in consortia, use sulfate as the main electron acceptor, consuming hydrogen and VFAs. Syntrophic propionate oxidizers are outcompeted by SRB under nonlimiting sulfate conditions. Butyrate is degraded at the same rate by syntrophic oxidizers and SRB. Additionally, SRB are more efficient hydrogen consumers than methanogenic archaea. SRB consume molecular hydrogen at higher rates in consideration of their superior scavenging capability (lower Ks facilitated by periplasmic location of the hydrogenase enzyme) (Kristjanson et al., 1992; Barber and Stuckey, 2000) and thermodynamics of sulfate reduction (Dries et al., 1998; Wang et al., 2008).

Accumulation of cells and optimal growth conditions are critical factors for successful operation of an anaerobic reactor. Microbial growth rates are constrained by low temperatures, substrate complexity, thermodynamical constraints and the need of physical separation of anaerobic catabolism phases (Barber and Stuckey, 1999). These limitations can be resolved using anaerobic baffled reactors (ABR). These reactors have additional advantages compared with other systems: they are cheap to build and operate, are tolerant to changes in hydraulic and organic shock loadings and have high biomass retention (Bachmann et al., 1985; Grobicki and Stuckey, 1991; Wang et al., 2004)). Few studies using ABRs in landfill leachate treatment have been reported. An ABR reached COD removal efficiencies of $80 \%$ for an OLR range of 1-7 g COD.L $\mathrm{L}^{-1}$ day $^{-1}$ (Reza et al., 2007). Wang and Shen (2000) reported an ABR used for the treatment of mixed wastewater of landfill leachate and municipal sewage.

We hypothesized that addition of sulfate to an ABR used for the treatment of landfill-leachate (a rich VFA substrate) could increase its organic matter removal efficiency by elimination of accumulated hydrogen. Effects of OLR and SLR over an ABR performance used on leachate treatment were studied using response surface methodology (RSM). A baffled reactor design was selected due to the following advantages: high retention and accumulation of biomass and its tolerance to volumetric loading providing a stable environment for microorganisms.

\section{MATERIALS AND METHODS}

\section{Bioreactor Configuration}

Lab-scale (2L) baffled reactors were used in this study (Figure 1). Reactors were built from polyethylene (PE) and rectangular in shape (length $25 \mathrm{~cm}$, width $15 \mathrm{~cm}$ and height $6.5 \mathrm{~cm}$ ), comprising five chambers. Reactors were seeded with anaerobic sludge $(10 \% \mathrm{vol} / \mathrm{vol})$, containing $15 \mathrm{~g} \mathrm{VSS} . \mathrm{L}^{-1}$, from the Antanas Sanitary Landfill Wastewater Treatment (ASLWT) Facility. During the initial start-up period of four weeks, reactors were fed with iron-sulfate at a SLR of $0.05 \mathrm{~g} \mathrm{SO}_{4}{ }^{2-} \cdot \mathrm{L}^{-1}$. day ${ }^{-1}$ in order to promote growth of sulfidogenic bacteria. Fresh ASL leachate (COD concentration of 4000-5000 mg/L) (Table 1) was provided by using a macrodrip set for a daily dose (Nebot et al. 1995). Average room temperature during reactor operation was maintained at $15 \pm 2{ }^{\circ} \mathrm{C}$. OLRs variations were obtained by using different HRTs. A single batch of fresh leachate was used for each SSOP in all reactors. Different levels of SLR 
were obtained by iron-sulfate addition to the influent. Reactors were operated at OLRs from 0.30 to $6.84 \mathrm{~g}$ COD.L ${ }^{-1}$.day ${ }^{-1}$ and SLRs from 0.06 to 0.13 g.L ${ }^{-1}$.day ${ }^{-1}$.

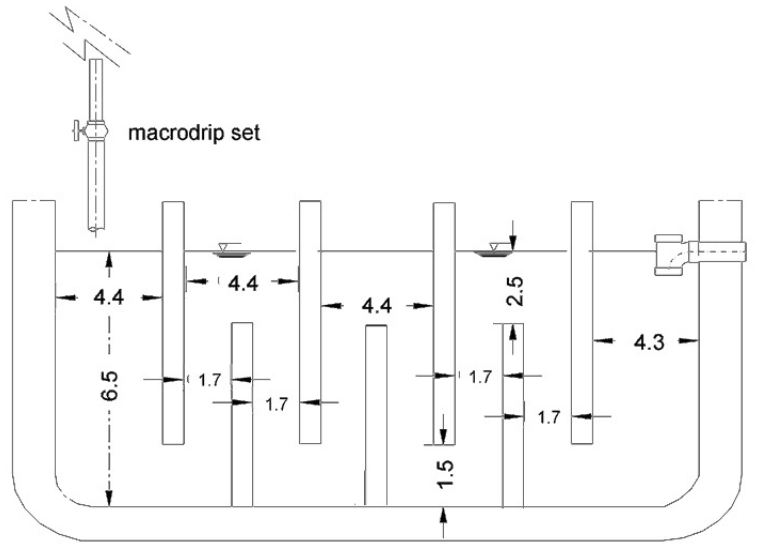

Figure 1: Scheme of the baffled reactor design used in this study. External dimensions are: length $25 \mathrm{~cm}$, width $15 \mathrm{~cm}$ and height $6.5 \mathrm{~cm}$. Internal dimensions are shown in the graph in cms. Effective reactor volume $=2 \mathrm{~L}$.

Table 1: Characteristics of landfill leachate taken from ASL in mg TSS. $\mathrm{L}^{-1}$.

\begin{tabular}{|l|r|}
\hline Parameter & \multicolumn{1}{|c|}{ Units } \\
\hline Chemical oxygen demand (COD) $\left(\mathrm{mg} . \mathrm{L}^{-1}\right)$ & $3966-5090$ \\
Volatile fatty acid (VFA) $\left(\mathrm{mg} . \mathrm{L}^{-1}\right)$ & $1678-2035$ \\
Total suspend solids (TSS) $\left(\mathrm{mg} . \mathrm{L}^{-1}\right)$ & $8.16-10.67$ \\
Volatile suspend solids (VSS) $\left(\mathrm{mg} . \mathrm{L}^{-1}\right)$ & $0.090-0.49$ \\
Sulfate $\left(\mathrm{mg} . \mathrm{L}^{-1}\right)$ & Not detected \\
pH & $6.52-7.98$ \\
\hline
\end{tabular}

\section{Experimental Design and Optimization}

The experimental design and data analysis were performed with the help of the Design Expert software (version 6.0.7, Stat Ease, Inc., Minneapolis, MN, USA) using the response surface model. This multivariate data analysis merges mathematical and statistical tools with the purpose of quantifying the influence of several variables on one or more response variables (Myers et al., 1989; Khuri, 2006; Zinatizadeh et al., 2006; Baş and Boyacı, 2007). Linear and quadratic models were used to predict optimal conditions. ANOVA analysis was used for testing the interaction between independent and dependent variables (response). Fitting of the polynomial model was tested by the correlation coefficient and statistically validated by the F-test. Model terms were only considered useful when their probability (P-value) offered a 95\% confidence level.

Seven reactors were used in this study. Each experimental run was defined as reactors working at the steady-state operating point (SSOP). A SSOP is defined as a reactor operating during at least three times its hydraulic retention time (HRT) and a variation of organic matter removal lower than $10 \%$.

Three phases were performed to find appropriate conditions for COD removal: exploratory, path of steepest ascent (PSA) and optimal conditions (Table 2). During the exploratory phase, initial operational points for RSM were estimated from the conditions employed for the anaerobic reactor used by ASLWT (SSOPs representing central points are the actual operational conditions). During the PSA phase, the contour plot defined in the exploratory phase was used to estimate a first-order equation that drives to the optimal point, the highest COD removal. Five operational points were used at step-size of $400 \mathrm{~g}$ COD.L ${ }^{-1}$.day ${ }^{-1}$ and $0.05 \mathrm{~g} \mathrm{SO}_{4}{ }^{2-} \cdot \mathrm{L}^{-1}$. day ${ }^{-1}$. The highest COD removal point obtained in the PSA phase was used as a central point for the optimization experiment. The loading rates used on this study ranged from 0.30 to $6.84 \mathrm{~g} \mathrm{COD. \textrm {L } ^ { - 1 }}$. $\mathrm{day}^{-1}$ and from 0.06 to $0.13 \mathrm{~g} \mathrm{SO}_{4}{ }^{2-} \cdot \mathrm{L}^{-1} \cdot \mathrm{day}^{-1}$.

Table 2: Experimental design describing variables in coded levels for exploratory, path of steepest ascent and optimization phases.

\begin{tabular}{|c|c|c|c|c|c|c|}
\hline \multirow{3}{*}{$\begin{array}{l}\text { Experiment } \\
\text { (run-SSOP) }\end{array}$} & \multicolumn{6}{|c|}{ Coded levels } \\
\hline & \multicolumn{2}{|c|}{ Exploratory } & \multicolumn{2}{|c|}{\begin{tabular}{|c|} 
Path of steepest \\
ascent
\end{tabular}} & \multicolumn{2}{|c|}{$\begin{array}{c}\text { Optimization } \\
\text { phase }\end{array}$} \\
\hline & OLR & SLR & OLR & SLR & OLR & SLR \\
\hline 1 & +1 & +1 & +1 & +1 & +1.4 & 0 \\
\hline 2 & +1 & -1 & +2 & +2 & +1 & +1 \\
\hline 3 & -1 & +1 & +3 & +3 & 0 & +1.4 \\
\hline 4 & -1 & -1 & +4 & +4 & -1 & +1 \\
\hline 5 & 0 & 0 & +5 & +5 & -1.4 & 0 \\
\hline 6 & 0 & 0 & +6 & +6 & -1 & -1 \\
\hline 7 & 0 & 0 & & & 0 & -1.4 \\
\hline 8 & & & & & +1 & -1 \\
\hline 9 & & & & & 0 & 0 \\
\hline 10 & & & & & 0 & 0 \\
\hline 11 & & & & & 0 & 0 \\
\hline
\end{tabular}

\section{Analytical Methods}

$400 \mathrm{~mL}$ were taken from each reactor effluent and analyzed for the next parameters following the Standard Methods (APHA 1992): COD (5220 D. Closed Reflux, Colorimetric Method), Sulphate (4500 E. Turbidimetric Method), VFA (5560 C. Distillation Method), TSS (2540 D. Total Suspended Solids Dried at $103-105{ }^{\circ} \mathrm{C}$ ) and VSS (2540 E. Fixed and Volatile Solids Ignited at $550{ }^{\circ} \mathrm{C}$ ). $\mathrm{pH}$ was measured immediately after sampling with a Metrohm $744 \mathrm{pH}$ meter. Samples were stored at $4^{\circ} \mathrm{C}$ for no more than 6 hours before being analyzed. 


\section{RESULTS}

The data listed in Tables 3 and 4 show wide variations in COD removal (CODr), VFA removal (VFAr), TSS removal (TSSr) and VSS removal (VSSr) during the screening and optimization phase. An optimal response point for CODr was found along the path of steepest ascent (Table 4). This point was chosen for further optimization. The ANOVA results for statistical significant models of the exploratory and optimization phase are summarized in Table 6 . The quality of the fit polynomial model was expressed by correlation coefficient $\left(r^{2}>0.94\right)$. No significant effect of OLR and SLR on VFA removal or $\mathrm{pH}$ value was observed. Effluent $\mathrm{pH}$ values compared with the influent $\mathrm{pH}$ ones were less than $1 \mathrm{pH}$ unit lower. During the optimization phase, no significant models explained the variation of VSS removal. Adequate precision of the signal-to-noise ratio for the selected models was greater than 6 . This ratio indicated adequate signals for these models to be used to navigate the design space.

\section{Effect of OLR and SLR on Reactor Performance} and Calculation of the Path of Steepest Ascent

The RSM approach requires performing several experiments in a predetermined range of step changes for each selected factor. These changes are large enough to have a significant change in the evaluated response and obscure noise associated with the other non-evaluated factors. OLR and SLR ranges for exploratory screening were estimated from the operational conditions used in an ABR treating ASL leachates. A three-level partial factorial design was used to estimate the OLR and SLR effects on CODr, VFAr, TSSr and VSSr (Table 3). Adequate response surface models were obtained for CODr, TSSr, and VSSr (Figure 2). In this exploratory screening, the highest removal of organic matter was reached for SSOP 9, in which the reactor was performing at the highest levels possible for OLR and SLR (OLR of $1.72 \mathrm{~g} \mathrm{COD.L^{-1 }}$.day ${ }^{-1}$ and SLR of 0.08 g.L $L^{-1} \cdot$ day $\left.^{-1}\right)$.

Table 3: Exploratory screening of the OLR and SLR levels effect on CODr, VFAr, TSSr and VSSr.

\begin{tabular}{|c|c|c|c|c|c|c|c|c|}
\hline \multirow{3}{*}{$\begin{array}{l}\text { Run } \\
\text { SSOP }\end{array}$} & \multicolumn{4}{|c|}{ Variables } & \multirow{2}{*}{\multicolumn{4}{|c|}{$\begin{array}{c}\text { Response values } \\
\text { Removal \% }\end{array}$}} \\
\hline & \multicolumn{2}{|c|}{ g. $\mathrm{L}^{-1} \cdot \mathrm{day}^{-1}$} & \multicolumn{2}{|c|}{ Coded Levels } & & & & \\
\hline & OLR & SLR & OLR & SLR & CODr & VFAr & TSSr & VSSr \\
\hline 1 & 0.43 & 0.025 & -1 & -1 & $27.06 \pm 1.64$ & $59.58 \pm 1.78$ & $30.25 \pm 0.29$ & $20.94 \pm 6.30$ \\
\hline 2 & 0.43 & 0.050 & -1 & 0 & $39.82 \pm 0.81$ & $52.97 \pm 1.77$ & $51.82 \pm 0.68$ & $42.99 \pm 12.33$ \\
\hline 3 & 0.43 & 0.075 & -1 & 1 & $37.47 \pm 0.98$ & $40.23 \pm 1.09$ & $41.52 \pm 0.34$ & $77.00 \pm 8.77$ \\
\hline 4 & 0.86 & 0.050 & 0 & 0 & $41.42 \pm 0.17$ & $52.87 \pm 1.14$ & $57.51 \pm 0.36$ & $91.78 \pm 7.81$ \\
\hline 5 & 0.86 & 0.050 & 0 & 0 & $41.60 \pm 0.42$ & $53.64 \pm 2.06$ & $57.17 \pm 0.17$ & $89.08 \pm 12.55$ \\
\hline 6 & 0.86 & 0.050 & 0 & 0 & $41.43 \pm 0.38$ & $47.89 \pm 2.83$ & $56.97 \pm 1.64$ & $81.65 \pm 21.28$ \\
\hline 7 & 1.72 & 0.025 & 1 & -1 & $37.13 \pm 0.65$ & $39.39 \pm 1.88$ & $47.45 \pm 0.37$ & $87.02 \pm 23.73$ \\
\hline 8 & 1.72 & 0.050 & 1 & 0 & $42.16 \pm 0.79$ & $50.96 \pm 2.80$ & $61.95 \pm 0.31$ & $59.97 \pm 11.25$ \\
\hline 9 & 1.72 & 0.075 & 1 & 1 & $48.66 \pm 3.63$ & $60.15 \pm 1.23$ & $62.61 \pm 0.29$ & $92.19 \pm 8.13$ \\
\hline
\end{tabular}

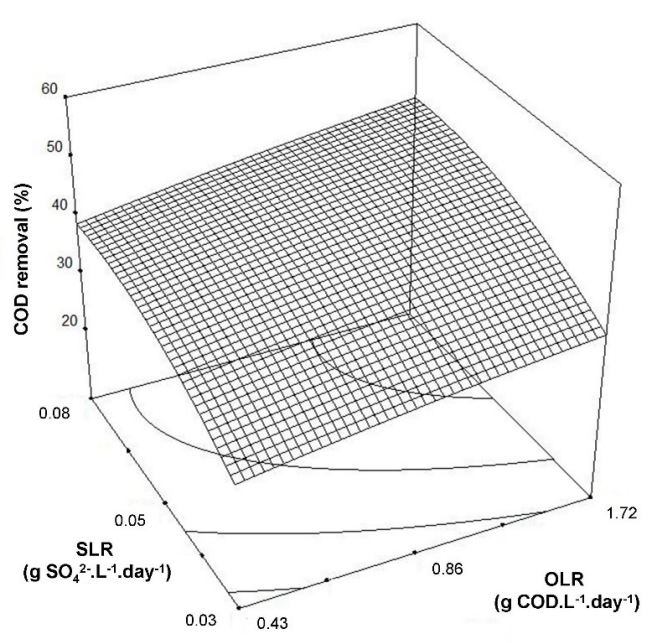

(a)

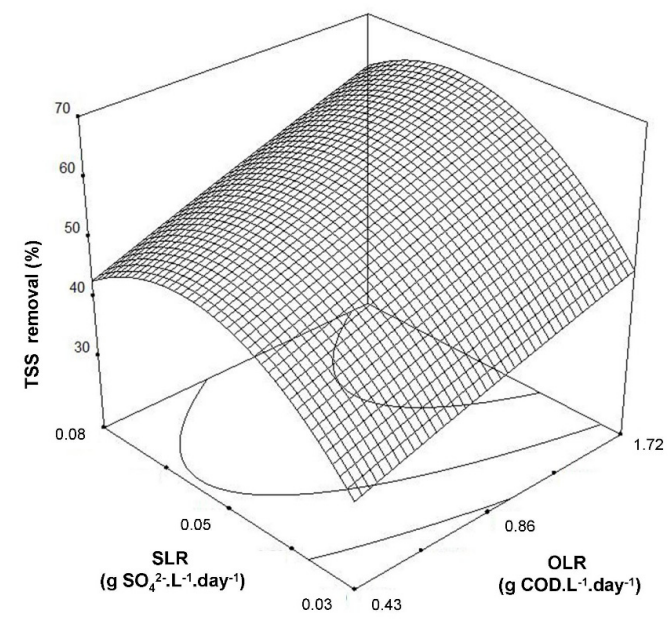

(b) 


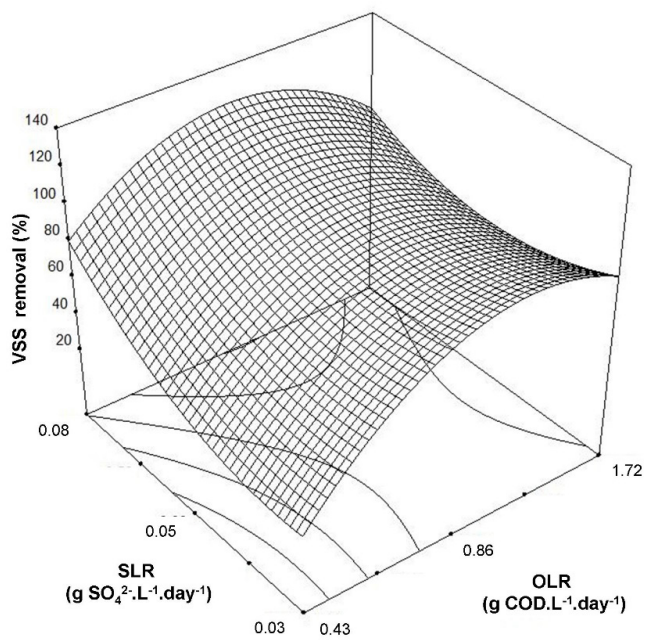

(c)

Figure 2: Exploratory screening. Response surface plot showing the effect of SLR and OLR on COD removal (panel a), TSS removal (panel b), and VSS removal (panel c).

Organic matter removal (measured as COD) was significantly influenced by OLR and SLR $(\mathrm{P}>0.05)$. These are the equations describing organic removal, TSSr and VSSr:

$$
\begin{aligned}
\mathrm{CODr} \% & =41.48+3.93 \mathrm{~A}+5.49 \mathrm{~B} \\
& +0.28 \mathrm{AB}-0.49 \mathrm{~A}^{2}-3.41 \mathrm{~B}^{2} \\
\mathrm{TSSr} \%= & 57.22+8.07 \mathrm{~A}+6.61 \mathrm{~B} \\
& +0.97 \mathrm{AB}-0.33 \mathrm{~A}^{2}-11.43 \mathrm{~B}^{2} \\
\mathrm{VSSr} \%= & 87.50+16.37 \mathrm{~A}+15.31 \mathrm{~B} \\
& -12.72 \mathrm{AB}-36.02 \mathrm{~A}^{2}+17.81 \mathrm{~B}^{2}
\end{aligned}
$$

where A and B represent OLR and SLR, respectively.

The CODr equation was used to define the steepest ascent path. New SSOPs were performed along the steepest ascent path until the CODr showed no further increase. This experiment was conducted in steps of 0.86 gCOD. $\mathrm{L}^{-1}$. day ${ }^{-1}$ for OLR and 0.014 $\mathrm{gSO}_{4}{ }^{2-} \cdot \mathrm{L}^{-1}$. day $^{-1}$ for SLR (Figure 3). Tukey analysis revealed a significant difference between SSOP 4 , the highest CODr value, and additional tested SSOPs. The highest CODr $(66 \%)$ value was recorded at an OLR of 3.58 g COD. $\mathrm{L}^{-1}$.day ${ }^{-1}$ and SLR of $0.09 \mathrm{~g}$ $\mathrm{SO}_{4}{ }^{2-} \cdot \mathrm{L}^{-1}$.day ${ }^{-1}$ (Table 4). This combination was used as the middle point for CODr optimization.

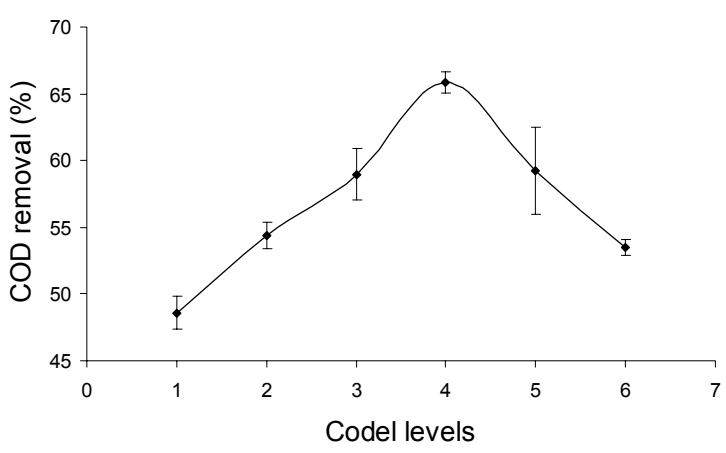

Figure 3: COD removal for each SSOP along the path of steepest ascent.

Table 4: COD removal during path of steepest ascent experiments.

\begin{tabular}{|c|c|c|c|c|c|}
\hline \multirow{2}{*}{ Run } & \multicolumn{4}{|c|}{ Variables } & \multirow{2}{*}{$\begin{array}{c}\text { Response values } \\
\text { \% of removal }\end{array}$} \\
\cline { 2 - 5 } & \multicolumn{2}{|c|}{ g.L $^{-\mathbf{1}}$.day $^{-1}$} & \multicolumn{2}{c|}{ Coded Levels } & CODr \\
\hline SOOP & OLR $^{\text {OLR }}$ & SLR & OLR & SLR & COD \\
\hline 1 & 0.99 & 0.050 & 1 & 1 & $48.58 \pm 1.73$ \\
2 & 1.23 & 0.063 & 2 & 2 & $54.43 \pm 1.41$ \\
3 & 1.93 & 0.076 & 3 & 3 & $58.97 \pm 2.74$ \\
4 & 3.58 & 0.089 & 4 & 4 & $65.75 \pm 2.41$ \\
5 & 4.84 & 0.102 & 5 & 5 & $59.19 \pm 4.62$ \\
6 & 5.19 & 0.115 & 6 & 6 & $53.50 \pm 0.79$ \\
\hline
\end{tabular}

\section{Optimization of COD Removal}

The optimization of CODr was performed by CCD with the fixed middle point of OLR of $3.58 \mathrm{~g}$ COD. $\mathrm{L}^{-1}$. day ${ }^{-1}$ and SLR of $0.09 \mathrm{~g} \mathrm{SO}_{4}{ }^{2-} \cdot \mathrm{L}^{-1}$. day $^{-1}$ and with an $\alpha$ value of \pm 1.4 to produce design rotability. 
The design matrix, the corresponding SSOPs and the CODr (experimental responses) are shown in Table 5. The ANOVA results indicated that the quadratic regression to produce the second-order model was significant for CODr and VSSr ( $\mathrm{P}$ value $<0.01)$ (Table 6). Only $1 \%$ of the total variation of COD removal was not explained by the model. This suggested that the proposed model is an accurate representation of the data in the experimental region. The response surface was generated (Figure 4) based on the following second-order equations for CODr and VSSr:

CODr $\%=65.23+0.16 \mathrm{~A}-0.093 \mathrm{~B}$

$$
-0.47 \mathrm{AB}-5.25 \mathrm{~A}^{2}-5.56 \mathrm{~B}^{2}
$$

$\operatorname{VSSr} \%=79.75+0.16 \mathrm{~A}-0.091 \mathrm{~B}$

$$
-0.46 \mathrm{AB}-3.85 \mathrm{~A}^{2}-4.15 \mathrm{~B}^{2}
$$

Table 5: Optimization of COD removal. The $\mathrm{COD} / \mathrm{SO}_{4}{ }^{-2}$ ratio and hydraulic retention time (HRT) for each

\begin{tabular}{|c|c|c|c|c|c|c|c|c|c|c|}
\hline \multirow{3}{*}{$\begin{array}{l}\text { Run } \\
\text { SSOP }\end{array}$} & \multicolumn{4}{|c|}{ Variables } & \multirow{2}{*}{\multicolumn{4}{|c|}{ Response values }} & \multirow{3}{*}{$\begin{array}{c}\mathrm{COD} / \mathrm{SO}_{4}{ }^{-2} \\
\text { Ratio } \\
\left({\left.\mathrm{g} . \mathrm{g}^{-1}\right)}^{-2}\right.\end{array}$} & \multirow{3}{*}{$\begin{array}{l}\text { HRT } \\
\text { days }\end{array}$} \\
\hline & \multicolumn{2}{|c|}{ g.L $^{-1} \cdot$ day $^{-1}$} & \multicolumn{2}{|c|}{ Coded Levels } & & & & & & \\
\hline & OLR & SLR & OLR & SLR & CODr & VFAr & TSSr & VSSr & & \\
\hline 1 & 0.30 & 0.090 & -1.4 & 0 & $54.42 \pm 0.10$ & $42.33 \pm 1.64$ & $71.76 \pm 1.32$ & $75.60 \pm 12.89$ & 3.33 & 1.39 \\
\hline 2 & 1.23 & 0.065 & -1 & -1 & $53.86 \pm 2.59$ & $55.00 \pm 1.78$ & $71.19 \pm 0.98$ & $87.60 \pm 9.88$ & 17.57 & 1.20 \\
\hline 3 & 1.23 & 0.115 & -1 & 1 & $54.82 \pm 0.45$ & $54.90 \pm 2.06$ & $72.15 \pm 0.78$ & $88.90 \pm 23.99$ & 10.25 & 1.20 \\
\hline 4 & 3.57 & 0.055 & 0 & -1.4 & $54.25 \pm 0.99$ & $59.63 \pm 1.98$ & $71.59 \pm 0.18$ & $77.00 \pm 12.90$ & 59.50 & 0.73 \\
\hline 5 & 3.57 & 0.090 & 0 & 0 & $65.69 \pm 1.70$ & $63.40 \pm 2.54$ & $80.18 \pm 0.23$ & $86.70 \pm 19.2$ & 39.67 & 0.73 \\
\hline 6 & 3.57 & 0.090 & 0 & 0 & $62.04 \pm 0.45$ & $59.80 \pm 2.32$ & $78.04 \pm 0.76$ & $80.90 \pm 20.98$ & 39.67 & 0.73 \\
\hline 7 & 3.57 & 0.090 & 0 & 0 & $63.36 \pm 0.34$ & $61.70 \pm 1.43$ & $78.88 \pm 0.56$ & $83.50 \pm 23.45$ & 39.67 & 0.73 \\
\hline 8 & 3.57 & 0.090 & 0 & 0 & $69.82 \pm 2.09$ & $62.64 \pm 1.09$ & $81.91 \pm 0.45$ & $84.50 \pm 19.77$ & 39.67 & 0.73 \\
\hline 9 & 3.57 & 0.125 & 0 & 1.4 & $53.69 \pm 0.23$ & $63.40 \pm 2.65$ & $71.02 \pm 0.32$ & $76.00 \pm 9.56$ & 27.46 & 0.73 \\
\hline 10 & 5.90 & 0.065 & 1 & -1 & $55.23 \pm 1.38$ & $63.70 \pm 1.14$ & $72.54 \pm 0.98$ & $75.60 \pm 8.76$ & 84.29 & 0.25 \\
\hline 11 & 5.90 & 0.115 & 1 & 1 & $54.32 \pm 1.17$ & $64.00 \pm 2.98$ & $71.65 \pm 1.09$ & $90.50 \pm 9.87$ & 49.17 & 0.25 \\
\hline 12 & 6.84 & 0.090 & 1.4 & 0 & $54.74 \pm 0.31$ & $59.80 \pm 2.34$ & $72.07 \pm 1.87$ & $88.80 \pm 23.45$ & 76.00 & 0.06 \\
\hline
\end{tabular}
SSOP was included.

Table 6: Analysis of variance (ANOVA) of the predicted response surface quadratic models for reactor

\begin{tabular}{|c|c|c|c|c|c|c|}
\hline & Source & Sum of squares & $\begin{array}{c}\text { Degree of } \\
\text { Freedom }\end{array}$ & Mean Square & F value & $\mathbf{P}>\mathbf{F}$ \\
\hline \multicolumn{7}{|l|}{ SCREENING } \\
\hline \multirow{5}{*}{ COD removal (\%) } & Model & 244.29 & 5 & 48.86 & 6.39 & 0.0788 \\
\hline & Residual & 22.93 & 3 & 7.64 & & \\
\hline & Lack of Fit & 22.91 & 1 & 22.91 & 2238.57 & 0.0004 \\
\hline & Pure Error & 0.02 & 2 & 0.01 & & \\
\hline & \multicolumn{6}{|c|}{$\mathrm{SD}=2.76, \mathrm{CV}=6.97, \mathrm{PRESS}=1237.08, \mathrm{R}-$ Squared $=0.9142$, Adeq Precision $=8.345$} \\
\hline \multirow[t]{5}{*}{ TSS removal (\%) } & Model & 869.69 & 5 & 173.94 & 19.16 & 0.0175 \\
\hline & Residual & 27.24 & 3 & 9.08 & & \\
\hline & Lack of Fit & 27.09 & 1 & 27.09 & 363.46 & 0.0027 \\
\hline & Pure Error & 0.15 & 2 & 0.075 & & \\
\hline & \multicolumn{6}{|c|}{$\mathrm{SD}=3.01, \mathrm{CV}=5.80, \mathrm{PRESS}=1463.20, \mathrm{R}-\mathrm{Squared}=0.9696$, Adeq Precision $=13.495$} \\
\hline \multirow[t]{5}{*}{ VSS removal (\%) } & Model & 4782.99 & 5 & 956.6 & 11.88 & 0.0343 \\
\hline & Residual & 241.56 & 3 & 80.52 & & \\
\hline & Lack of Fit & 186.52 & 1 & 186.52 & 6.78 & 0.1213 \\
\hline & Pure Error & 55.04 & 2 & 27.52 & & \\
\hline & \multicolumn{6}{|c|}{$\mathrm{SD}=8.97, \mathrm{CV}=12.57, \mathrm{PRESS}=10195.00, \mathrm{R}-$ Squared $=0.9519$, Adeq Precision $=8.649$} \\
\hline \multicolumn{7}{|l|}{ OPTIMIZATION } \\
\hline \multirow[t]{6}{*}{ COD removal (\%) } & Model & 313.32 & 5 & 62.66 & 10.67 & 0.006 \\
\hline & Residual & 35.24 & 6 & 5.87 & & \\
\hline & Lack of Fit & 0.27 & 3 & 0.089 & 7.65E-03 & 0.9989 \\
\hline & Pure Error & 34.97 & 3 & 11.66 & & \\
\hline & Cor Total & 348.56 & & & & \\
\hline & \multicolumn{6}{|c|}{$\mathrm{SD}=2.42, \mathrm{CV}=4.18, \mathrm{PRESS}=64.07, \mathrm{R}-\mathrm{Squared}=0.8989$, Adeq Precision $=6.625$} \\
\hline \multirow[t]{5}{*}{ TSS removal (\%) } & Model & 172.32 & 5 & 34.46 & 23.45 & 0.0007 \\
\hline & Residual & 8.82 & 6 & 1.47 & & \\
\hline & Lack of Fit & 0.26 & 3 & 0.088 & 0.031 & 0.9913 \\
\hline & Pure Error & 8.55 & 3 & 2.85 & & \\
\hline & \multicolumn{6}{|c|}{$\mathrm{SD}=1.21, \mathrm{CV}=1.63, \mathrm{PRESS}=17.09, \mathrm{R}-\mathrm{Squared}=0.9513$, Adeq Precision $=9.954$} \\
\hline
\end{tabular}
performance. 


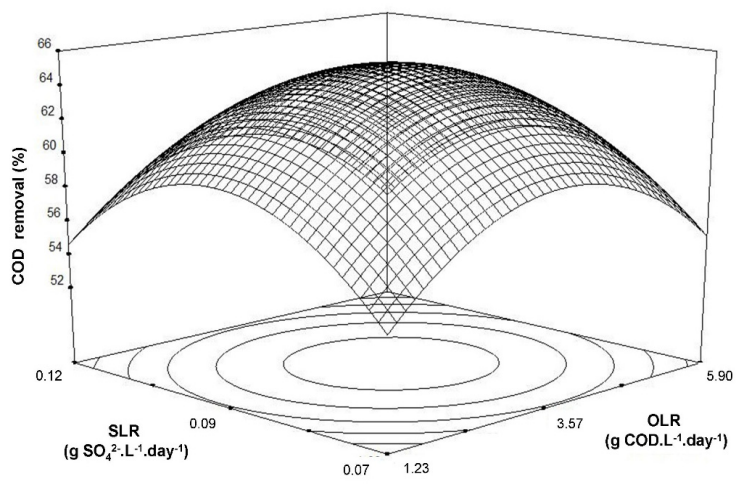

(a)

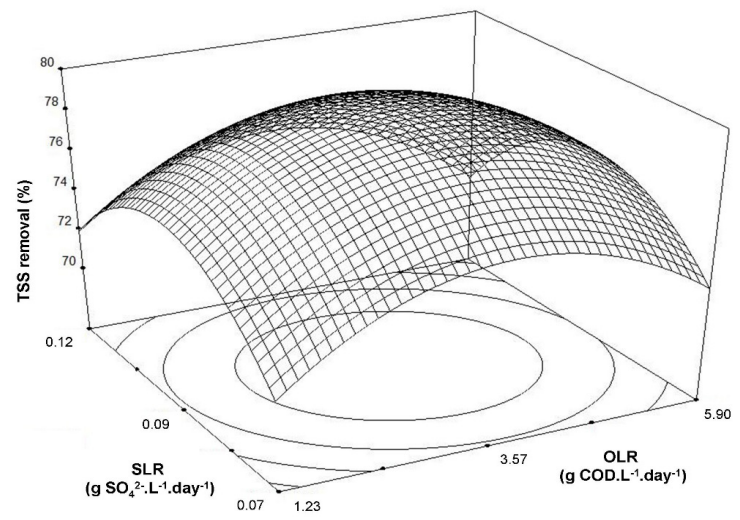

(b)

Figure 4: COD removal optimization. Three-dimensional contour plots showing the effect of SLR and OLR on COD removal (panel a) and TSS removal (panel b)

\section{DISCUSSION}

We hypothesized that sulfate addition should improve ABR performance used in leachate treatment. The results of the present study support that statement. An optimum point for CODr $(66 \%)$ was observed with a SLR of $0.09 \mathrm{~g} \mathrm{SO}_{4}^{-2} \cdot \mathrm{L}^{-1}$.day ${ }^{-1}$ and HRT of 0.73 days, a quarter of the HRT used in the ABR located in ASL. A further increase in the volumetric loading rate decreased the reactor performance by bacterial washout.

The $\mathrm{COD} / \mathrm{SO}_{4}{ }^{2-}$ ratio has been used as a criterion to predict the dominance of SRB or MPB in the anaerobic environment. The theoretical feed $\mathrm{COD} / \mathrm{SO}_{4}{ }^{2-}$ ratio of 0.67 is the critical stoichiometric value required for complete removal of OM by sulfate reduction (Lens et al., 1998). At lower $\mathrm{COD} / \mathrm{SO}_{4}{ }^{2-}$ ratios, $\mathrm{SRB}$ tends to dominate the reactor microbial community, whereas MPB dominates at higher ratios (De Smul et al., 1999; Vallero et al., 2003; O'Reilly and Colleran, 2006). In consideration of the thermodynamic properties of sulfate as an electron acceptor, microbial communities dominated by SRB have a higher growth rate that results in increased reactor performance. However, greater reactor performance has been observed at $\mathrm{COD} / \mathrm{SO}_{4}{ }^{2-}$ ratios over 0.67 . In other cases, little, if any effect of sulfate concentration on anaerobic reactor performance was observed (Choi and Rim, 1991; Henry and Prasad, 2000).

This work analyzed the performance of an anaerobic reactor at $\mathrm{COD} / \mathrm{SO}_{4}{ }_{4}^{2-}$ ratios ranging from 3.33 to 84.29. Previous studies had reported $\mathrm{COD} / \mathrm{SO}_{4}{ }^{2-}$ ratios ranging from 6.6 to 1.7 as optimal for $\mathrm{CODr}$ (Choi and Rim, 1991; Friedl et al., 2009; Mockaitis et al., 2010; Silva et al., 2011; Camiloti et al., 2013).
The highest CODr observed in this study was obtained when the $\mathrm{COD} / \mathrm{SO}_{4}{ }^{2-}$ ratio was 40 . This value fairly exceeds any previous ratio reported as being optimal for CODr. At this ratio, sulfate was not responsible for significant removal of organic matter but increased the overall performance of the reactor. $\mathrm{OM}$ was mainly consumed via methanogenesis.

Improved performance of $\mathrm{ABRs}$ at high $\mathrm{COD} / \mathrm{SO}_{4}{ }^{2-}$ ratios can be explained by the following two assumptions: a) Landfill leachate was mainly composed of acetate. Under methanogenic conditions inside the landfill, acetate accumulates two or three times faster than propionate or butyrate (Schink, 1997; Mormile et al., 1996). b) Previous researches have revealed a differential degradation of VFA under sulfidogenic conditions. Acetate is poorly consumed at high sulfate loading rates. Propionate is preferentially degraded by BRS, while the butyrate degradation rate is not affected by sulfate concentration (O'Reilly and Colleran, 2006; Bharati and Kumar, 2012). Based on this scenario, the acetate degradation rate is affected by sulfate reduction, provoking its inhibition at low $\mathrm{COD} / \mathrm{SO}_{4}{ }^{2-}$ ratio (Omil et al. 1998; Barber and Stuckey, 2000). At high $\mathrm{COD} / \mathrm{SO}_{4}{ }^{2-}$ ratio, acetogenesis is not inhibited by sulfate reduction, while the overall reactor performance is improved by molecular hydrogen removal (JWH et al., 1994; Kalyuzhnyi et al., 1998; Dar et al., 2009; Zhao et al., 2010). If $\mathrm{SO}_{4}{ }^{2-}$ is present, $\mathrm{SRB}$ consumes molecular hydrogen at higher rates compared with methanogenic archeas because of its superior scavenging capability (Kristjansson et al., 1982). Poor reactor performance at $\mathrm{COD} / \mathrm{SO}_{4}{ }^{-2}$ ratios higher than 40 is explained by the scarcity of sulfate for significant $\mathrm{H}_{2}$ removal. 
A complementary explanation for improved ABR performance at such $\mathrm{COD} / \mathrm{SO}_{4}{ }^{2-}$ ratio is the spatial distribution of microorganisms and tolerance to changing $\mathrm{COD} / \mathrm{SO}_{4}{ }^{2-}$ ratios of baffled reactors (Vossoughi et al., 2003). ABRs exhibit a plug flow behavior that, in combination with compartmentalization, provokes staging of VFA degradation (Vallero et al., 2003; Vossoughi et al., 2003; Krishna et al., 2009). Previous reports have indicated that, when an ABR is fed with sulfate, more than a half of the effluent $\mathrm{OM}$ and sulfate is removed in the first compartment. Propionate and butyrate are mainly degraded in the first compartment, resulting in acetate accumulation. Accumulated acetate is degraded in the subsequent compartments where sulfate is almost nonexistent or abandons the reactor as residual acetate in the effluent (Vallero et al., 2003). At higher SLR, sulfidogenic conditions are imposed on the whole reactor, slowing or inhibiting acetate degradation. The highest sulfate reduction rates do not occur in the first compartment, but in the subsequent ones (Vossoughi et al., 2003). ABRs used in this study were exposed to a range of $\mathrm{COD} / \mathrm{SO}_{4}{ }^{-2}$ ratios from 3.3 to 84.29 , exhibiting stable operation at low ratios. At a $\mathrm{COD} / \mathrm{SO}_{4}{ }^{-2}$ ratio of 40 , sulfidogenic conditions can only prevail in the first compartment. A previous research showed that $\mathrm{COD} / \mathrm{SO}_{4}{ }^{-2}$ ratios from 30 to 3 had a slight effect on COD removal (Borghei and Poorhashem, 2008).

A similar statistical approach for assessing the effect of OLR and SLR over CODr was previously reported. An anaerobic sequencing batch biofilm reactor was optimized using the Taguchi experimental design. Improved conditions for CODr $(50 \%$ increase) were observed at an OLR of 3.5 g.L. ${ }^{-1}$.day ${ }^{-1}$, neutral $\mathrm{pH}, \mathrm{BOD} / \mathrm{COD}$ ratio of 0.5 , and low sulfate concentration $(0.7 \mathrm{~g} / \mathrm{L})$ (Venkata Mohan et al., 2005). That work reached similar conclusions to those presented here: optimal reactor performance is reached at high OLR and low sulfate concentrations. Coincidentally, both studies reported a similar optimal OLR value (3.5 g.L $\mathrm{L}^{-1}$.day $\left.{ }^{-1}\right)$ for CODr.

\section{CONCLUSION}

The effect of OLR and SLR on the performance of an ABR treating landfill leachate was studied. The results revealed that, with appropriate sulfate feeding, OLR can be increased without affecting reactor performance. A quadratic effect of OLR and SLR on CODr was observed. The highest COD removal (65\%) was reached at a HRT of 18 hours ( 0.73 days),

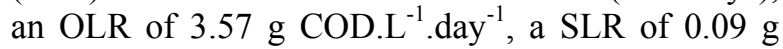

$\mathrm{SO}_{4}{ }^{2-} \cdot \mathrm{L}^{-1} \cdot \mathrm{day}{ }^{-1}$, and a $\mathrm{COD} / \mathrm{SO}_{4}{ }_{4}^{2}$ ratio of 40 . An acceptable CODr (54\%) was maintained even at a HRT 12 times lower (1.5 hours). A similar CODr for treatment of landfill leachates with low organic matter concentration $\left(<10000 \mathrm{mgCOD} . \mathrm{L}^{-1}\right)$ has previously reported. However, the ABR described by this research is operated at an OLR three times higher than those previously been reported (Burbano-Figueroa, 2002; Castrillon et al., 2010; Yilmaz et al., 2012). Similar CODr performance at OLRs near to $4 \mathrm{~g}$ COD. $\mathrm{L}^{-1}$.day ${ }^{-1}$ were achieved by mixing leachate with municipal sewage (Wang and Shen, 2000) or feeding leachates with high concentrations of organic matter $(>10000$ $\mathrm{mg}$ COD. $\left.\mathrm{L}^{-1}\right)$ to sequential sulfidogenic and methanogenic reactors (Nedwell and Reynolds, 1996) or up-flow anaerobic sludge blanket (UASB) reactors (Kettunen and Rintala, 1998).

\section{ACKNOWLEDGEMENTS}

The authors acknowledge Universidad de Nariño and Empresa Metropolitana de Aseo, EMAS S.A. for their financial support of this work.

\section{NOMENCLATURE}

ASL Antanas Sanitary Landfill

ASLWT Antanas Sanitary Landfill Wastewater

COD Chemical Demand of Oxigen $\left(\mathrm{mg} \mathrm{O}_{2} \cdot \mathrm{L}^{-1}\right.$ or $\left.\mathrm{g} \mathrm{O}_{2} \cdot \mathrm{L}^{-1}\right)$

CODr COD removal efficiency (\%)

HRT Hydraulic Retention Time (days)

HS Hydrogen Sulphide

OLR Organic Loading Rate (g COD.L ${ }^{-1}$. day $^{-1}$ )

PSA Path of Steepest Ascent

PE Polyethylene

RSM Response Surface Methodology

ABR Anaerobic Baffled Reactor

SLR Sulfate Loading Rate $\left(\mathrm{g} \mathrm{SO}_{4}{ }^{2-} \cdot \mathrm{L}^{-1} \cdot\right.$ day $\left.^{-1}\right)$

SRB Sulfate-Reducing Bacteria

SSOP Steady State Operation Point

TSS Total Suspend Solid (mg TSS.L ${ }^{-1}$ )

$\mathrm{TSSr} \quad \mathrm{TSS}$ removal efficiency (\%)

VFA Volatile Fatty Acid $\left(\mathrm{mg} \mathrm{CH} \mathrm{COO}^{-} \mathrm{L}^{-1}\right)$

VFAr VFA removal efficiency (\%)

VSS Volatile Suspended Solids (mg VSS.L ${ }^{-1}$ )

VSSr VSS removal efficiency (\%)

\section{REFERENCES}

APHA, American Public Health Association. Métodos Normalizados Para El Análisis de Aguas Potables 
y Residuales. Ediciones Díaz de Santos, Madrid (1992). (In Spanish).

Barber, W. P., Stuckey, D., Effect of sulfate reduction on chemical oxygen demand removal in an anaerobic baffled reactor. Water Environment Research, 72, 593-601 (2000).

Bachmann, A., Beard, V. L., McCarty, P. L., Performance characteristics of the anaerobic baffled reactor. Water Research, 19(1), 99-106 (1985). (In Spanish).

Baş, D., Boyac1, I. H., Modeling and optimization I: Usability of response surface methodology. Journal of Food Engineering, 78(3), 836-845 (2007).

Bashir, M. J. K., Aziz, H. A., Yusoff, M. S., Aziz, S. Q. and Mohajeri S., Stabilized sanitary landfill leachate treatment using anionic resin treatment optimization by response surface methodology. Journal of Hazardous Materials, 182(1), 115-122 (2010).

Berrueta, J., Castrillón, L., Anaerobic treatment of leachates in UASB reactors. Journal of Chemical Technology and Biotechnology, 54(1), 33-37 (1992).

Bharati, B., Kumar, G. P., A study on efficiency of five different carbon sources on sulfate reduction. Journal of Environmental Research and Development, 7(1), 416-420 (2012).

Borghei, M., Poorhashem, Q., Sulphate reduction in a three-stage packed-bed anaerobic bioreactor. World Environmental and Water Resources Congress 2008. Honolulu (2008).

Burbano-Figueroa, O., Tratamiento Biologico de lixiviados del relleno sanitario Antanas por filtros anaerobios. BSc Biology Dissertation, Universidad de Nariño - Colombia (2008). (In Spanish).

Camiloti, P. R., Mockaitis, G., Domingues Rodrigues, J. A., Rissato, M. H., Damianovic, Z., Foresti, E., Zaiat, M., Innovative anaerobic bioreactor with fixed-structured bed (ABFSB) for simultaneous sulfate reduction and organic matter removal. Journal of Chemical Technology and Biotechnology, 89(7), 1044-1050 (2014).

Choi, E., Rim, J. M., Competition and inhibition of sulfate reducers and methane producers in anaerobic treatment. Water Science \& Technology, 23(7), 1259-1264 (1991).

Dar, S. A., Bijmans, M. F. M., Dinkla, I. J. T., Geurkink, B., Lens, P. N. L., Dopson, M., population dynamics of a single-stage sulfidogenic bioreactor treating synthetic zinc-containing waste streams. Microbial Ecology, 58(3), 529-537 (2009).

De Smul, A., Goethals, L., Verstraete, W., Effect of COD to sulphate ratio and temperature in expandedgranular-sludge-blanket reactors for sulphate reduction. Process Biochemistry, 34(4), 407-416 (1999).

Dries, J., De Smul, A., Goethals, L., Grootaerd, H., Verstraete, W., High rate biological treatment of sulfate-rich wastewater in an acetate-fed EGSB reactor. Biodegradation, 9(2), 103-111 (1998).

Friedl, G., Mockaitis, G., Rodrigues, J. A. D., Ratusznei, S. M., Zaiat, M., Foresti, E., AnSBBR Applied to organic matter and sulfate removal interaction effect between feed strategy and COD/sulfate ratio. Applied Biochemistry and Biotechnology, 159(1), 95-109 (2009).

García, H., Rico, J. L., García, P. A., Comparison of anaerobic treatment of leachates from an urbansolid-waste landfill at ambient temperature and at $35^{\circ} \mathrm{C}$. Bioresource Technology 58(3), 273277 (1996).

Ghafari, S., Aziz, H. A., Isa, M. H., Zinatizadeh, A. A., Application of response surface methodology (RSM) to optimize coagulation-flocculation treatment of leachate using poly-aluminum chloride (PAC) and alum. Journal of Hazardous Materials, 163(2), 650-656 (2009).

Gopala Krishna, G. V. T., Kumar, P., Kumar, P., Treatment of low-strength soluble wastewater using an anaerobic baffled reactor (ABR). Journal of Environmental Management, 90(1), 166-176 (2009).

Grobicki, A., Stuckey, D. C., Performance of the anaerobic baffled reactor under steady-state and shock loading conditions. Biotechnology and Bioengineering, 37(4), 344-355 (1991).

Henry, J., Prasad, D., Anaerobic Treatment of landfill leachate by sulfate reduction. Water Science and Technology, 41(3), 239-246 (2000).

J. W. H., S., Elferink, O., Visser, A., Hulshoff Pol, L. W., Stams, A. J. M., Sulfate reduction in methanogenic bioreactors. FEMS Microbiology Reviews, 15(2), 119-136 (1994).

Kalyuzhnyi, S., Fedorovich, V., Lens, P., Hulshoff Pol, L. W., L., Lettinga, G., Mathematical modelling as a tool to study population dynamics between sulfate reducing and methanogenic bacteria. Biodegradation, 9(3), 187-199 (1998).

Kettunen, R. H., Hoilijoki, T. H., Rintala, J. A., Anaerobic and sequential anaerobic-aerobic treatments of municipal landfill leachate at low temperatures. Bioresource Technology, 58(1), 31-40 (1996).

Kettunen, R. H., Rintala, J. A., Performance of an on-site UASB reactor treating leachate at low temperature. Water Research, 32(3), 537-546 (1998).

Khuri, A. I., Response Surface Methodology and Related Topics. World Scientific Pub Co Inc., 
Singapore (2006).

Kristjansson, J. K., Schönheit, P., Thauer, R. K., Different Ks values for hydrogen of methanogenic bacteria and sulfate reducing bacteria: An explanation for the apparent inhibition of methanogenesis by sulfate. Archives of Microbiology, 131 (3), 278-282 (1982).

Kulikowska, D., Klimiuk, E., The effect of landfill age on municipal leachate composition. Bioresource Technology, 99(13), 5981-5985 (2008).

Lens, P. N. L., Visser, A., Janssen, A. J. H., Hulshoff Pol, L. W., Lettinga, G., Biotechnological treatment of sulfate-rich wastewaters. Critical Reviews in Environmental Science and Technology, 28(1), 4188 (1998).

Lettinga, G., Rebac, S., Parshina, S., Nozhevnikova, A., Van Lier, J. B., Stams, A. J. M., High-rate anaerobic treatment of wastewater at low temperatures. Applied and Environmental Microbiology, 65(4), 1696-1702 (1999).

Mockaitis, G., Friedl, G. F., Rodrigues, J., Ratusznei, S. M., Zaiat, M., Foresti, E., Influence of feed time and sulfate load on the organic and sulfate removal in an ASBR. Bioresource Technology, 101(17), 6642-6650 (2010).

Mormile, M. R., Gurijala, K. R., Robinson, J. A., McInerney, M. J., Suflita, J. M., The Importance of hydrogen in landfill fermentations. Applied and Environmental Microbiology, 62(5), 15831588 (1996).

Myers, R. H., Khuri, A. I., Carter, W. H., Response Surface Methodology 1966-1988. Technometrics, 31(2), 137-157 (1989).

Nebot, E., Romero, L. I., Quiroga, J. M., Sales, D., Effect of the feed frequency on the performance of anaerobic filters. Anaerobe, 1(2), 113-120 (1995).

Noguera, K. M., Olivero, J. T., Los rellenos sanitarios en Latinoamerica: Caso Colombiano. Rev. Acad. Colomb. Cienc., 34(132), 347-356 (2010). (In Spanish).

O'Reilly, C., Colleran, E., Effect of influent COD/ $\mathrm{SO} 42-$ ratios on mesophilic anaerobic reactor biomass populations physico-chemical and microbiological properties. FEMS Microbiology Ecology, 56(1), 141-153 (2006).

Omil, F., Lens, P., Visser, A., Hulshoff Pol, L. W., Lettinga, G., Long-term competition between sulfate reducing and methanogenic bacteria in UASB reactors treating volatile fatty acids. Biotechnology and Bioengineering, 57(6), 676-685 (1998).

Renou, S., Givaudan, J. G., Poulain, S., Dirassouyan, F., Moulin, P., Landfill leachate treatment review and opportunity. Journal of Hazardous Materials,
150(3), 468-493 (2008).

Schink, B., Energetics of syntrophic cooperation in methanogenic degradation. Microbiology and Molecular Biology Reviews, 61(2), 262-280 (1997).

Silva, A. J., Domingues, M. R., Hirasawa, J. S., Varesche, M. B., Foresti, E., Zaiat, M., Kinetic modeling and microbial assessment by fluorescent in situ hybridization in anaerobic sequencing batch biofilm reactors treating sulfate-rich wastewater. Brazilian Journal of Chemical Engineering, 28(2), 209-219 (2011).

SSPD, Superintendencia de Servicios Públicos Domiciliarios. Situación de La Disposición Final de Residuos Sólidos En Colombia. Imprenta Nacional, Bogota (2008). Available from $<$ http//www. superservicios.gov.co/c/document_library/get_file 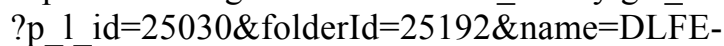 8354.pdf $>$ (Accessed: June 15, 2012). (In Spanish).

Tchobanoglous, G., Kreith, F., Handbook of Solid Waste Management. McGraw-Hill, New York (2002).

Vallero, M., Lens, P., Bakker, C., Lettinga, G., Sulfidogenic volatile fatty acid degradation in a baffled reactor. Water Science \& Technology, 48(3), 81-88 (2003).

Vallero, M., Trevino, R. H. M., Paulo, P. L., Lettinga, G., Lens, P. N. L., Effect of sulfate on methanol degradation in thermophilic $\left(55^{\circ} \mathrm{C}\right)$ methanogenic UASB reactors. Enzyme and Microbial Technology, 32(6), 676-687 (2003).

Venkata Mohan, S., Chandrasekhara Rao, N., Krishna Prasad, K., Murali Krishna, P., Sreenivas Rao, R., Sarma, P. N., Anaerobic treatment of complex chemical wastewater in a sequencing batch biofilm reactor process optimization and evaluation of factor interactions using the Taguchi dynamic DOE methodology. Biotechnology and Bioengineering, 90(6), 732-745 (2005).

Vossoughi, M., Shakeri, M., Alemzadeh, I., Performance of anaerobic baffled reactor treating synthetic wastewater influenced by decreasing COD/SO4 ratios. Chemical Engineering and Processing Process Intensification, 42(10), 811-816. (2003).

Wang, A., Ren, N., Wang, X., Lee, D., Enhanced sulfate reduction with acidogenic sulfate-reducing bacteria. Journal of Hazardous Materials, 154(1), 1060-1065 (2008).

Wang, J., Huang, Y., Zhao, X., Performance and characteristics of an anaerobic baffled reactor. Bioresource Technology, 93(2), 205-208 (2008).

Wiszniowski, J., Robert, D., Surmacz-Gorska, J., Miksch, K., Weber, J. V., Landfill leachate treatment methods a review. Environmental Chemistry Letters, 4(1), 51-61 (2006). 
Yilmaz, T., Erdirencelebi, D., Berktay, A., Effect of $\mathrm{COD} / \mathrm{SO} 4$ ratio on anaerobic treatment of landfill leachate during the start-up period. Environmental Technology, 33(3), 313-320 (2012).

Zhao, Y. G., Li, X. W., Wang, J. C., Bai, J., Tian, W. J., Performance of a sulfidogenic bioreactor and bacterial community shifts under different alkalinity levels. Bioresource Technology, 101(23),
9190-9196 (2010).

Zinatizadeh, A. A. L., Mohamed, A. R., Abdullah, A. Z., Mashitah, M. D., Hasnain Isa, M., Najafpour, G. D., Process modeling and analysis of palm oil mill effluent treatment in an up-flow anaerobic sludge fixed film bioreactor using response surface methodology (RSM). Water Research, 40(17), 3193-3208 (2006). 